\title{
N-Substituted Piperazines Abused by Humans Mimic the Molecular Mechanism of 3,4-Methylenedioxymethamphetamine (MDMA, or 'Ecstasy')
}

\author{
Michael H Baumann*,', Robert D Clark', Allison G Budzynski', John S Partilla', Bruce E Blough² and \\ Richard B Rothman' \\ 'Clinical Psychopharmacology Section, Intramural Research Program, National Institute on Drug Abuse, National Institutes of Health, Baltimore, \\ MD, USA; ${ }^{2}$ Chemistry and Life Sciences Group, Research Triangle Institute International, Research Triangle Park, NC, USA
}

3,4-Methylenedioxymethamphetamine (MDMA, or 'Ecstasy') is an illicit drug that stimulates the release of serotonin (5-HT) and dopamine (DA) from neurons. Recent evidence reveals that drug users are ingesting piperazine analogs, like I-benzylpiperazine (BZP, or 'A2') and I-(m-trifluoromethylphenyl)piperazine (TFMPP, or 'Molly'), to mimic psychoactive effects of MDMA. In the present study, we compared the neurochemistry of MDMA, BZP, and TFMPP in rats. The effects of MDMA, BZP, and TFMPP on transporter-mediated efflux of $\left[{ }^{3} \mathrm{H}\right] 5-\mathrm{HT}$ and $\left.{ }^{3} \mathrm{H}\right] \mathrm{MPP}^{+}$(DA transporter substrate) were determined in synaptosomes. The effects of drugs on extracellular levels of 5-HT and DA were examined using in vivo microdialysis in conscious rats. MDMA evoked transporter-mediated release of $\left[{ }^{3} \mathrm{H}\right] 5-\mathrm{HT}$ and $\left[{ }^{3} \mathrm{H}\right] \mathrm{MPP}^{+}$. BZP released $\left.{ }^{3} \mathrm{H}\right] \mathrm{MPP}{ }^{+}$, whereas TFMPP was a selective releaser of $\left[{ }^{3} \mathrm{H}\right] 5-\mathrm{HT}$. MDMA $(\mathrm{I}-3 \mathrm{mg} / \mathrm{kg}, \mathrm{i} . \mathrm{V}$. increased dialysate 5-HT and DA in a dose-related fashion, with actions on 5-HT being predominant. BZP (3-10 mg/ $/ \mathrm{kg}$, i.v.) elevated dialysate DA and 5-HT, while TFMPP (3-10 mg/kg, i.v.) elevated 5-HT. Administration of BZP plus TFMPP at a I:I ratio (BZP/TFMPP) produced parallel increases in dialysate $5-\mathrm{HT}$ and DA; a $3 \mathrm{mg} / \mathrm{kg}$ dose of BZP/TFMPP mirrored the effects of MDMA. At a $10 \mathrm{mg} / \mathrm{kg}$ dose, BZP/TFMPP increased dialysate DA more than the summed effects of each drug alone, and some rats developed seizures. Our results show that BZP/TFMPP and MDMA share the ability to evoke monoamine release, but dangerous drug-drug synergism may occur when piperazines are coadministered at high doses.

Neuropsychopharmacology (2005) 30, 550-560, advance online publication, 20 October 2004; doi: I 0.1038/sj.npp. 1300585

Keywords: dopamine; in vivo microdialysis; release; serotonin; transporters

\section{INTRODUCTION}

Misuse of the illicit drug, 3,4-methylenedioxymethamphetamine (MDMA, or 'Ecstasy'), is increasing worldwide, especially among children and young adults (Landry, 2002). The allure of MDMA is likely related to its unique profile of psychotropic actions. Human subjects report that MDMA induces a pleasurable mix of stimulant-like and hallucinogen-like effects, coupled with feelings of increased emotional sensitivity and closeness to others (Vollenweider et al, 1998). The neurobiological mechanisms underlying psychoactive effects of MDMA seem to involve the release of 5HT, and possibly DA, from nerve cells in the brain (Liechti and Vollenweider, 2001). At the molecular level, MDMA

*Correspondence: Dr MH Baumann, Clinical Psychopharmacology Section, IRP, NIDA, NIH, 5500 Nathan Shock Drive, Baltimore, MD 21224, USA, Tel: + |-410-550-1754, Fax: + |-410-550-2997,

E-mail: mbaumann@intra.nida.nih.gov

Received 19 January 2004; revised 26 August 2004; accepted 31 August 2004

Online publication: 9 September 2004 at http://www.acnp.org/citations/ Npp09090404024/default.pdf serves as a substrate for 5-HT transporters (SERTs) and DA transporters (DATs), thereby triggering nonexocytotic release of transmitter molecules from 5-HT and DA neurons (Green et al, 2003).

Preclinical studies show that high-dose administration of MDMA causes long-term changes in central 5-HT systems (Lyles and Cadet, 2003). These changes include depletions of tissue 5-HT, inactivation of tryptophan hydroxylase, and loss of SERT binding sites in terminal fields throughout the forebrain. Taken together, these data suggest that MDMA produces 5-HT neurotoxicity in animals. Emerging clinical evidence demonstrates that MDMA can cause 5-HT dysfunction in humans under some circumstances (Parrott, 2002). Moreover, habitual users of MDMA exhibit psychological problems, memory disturbances, and cognitive impairments that could be secondary to drug-induced 5-HT deficits (Morgan, 2000).

Given the potential risks associated with MDMA, some drug users have sought to identify safe and legal alternatives. For example, $N$-substituted piperazine analogs, like 1-benzylpiperazine (BZP, or 'A2') and 1-( $m$-trifluoromethylphenyl)piperazine (TFMPP, or 'Molly'), have been 
referred to as 'Legal E' or 'Legal X' compounds on Internet websites (Drug Enforcement Administration, 2001; see Erowid piperazine vault, 2004). The chemical structures of MDMA and some representative piperazine compounds are shown in Figure 1. Drug users in European countries have reportedly ingested the combination of BZP plus TFMPP (BZP/TFMPP) in an attempt to mimic the MDMA subjective experience (see de Boer et al, 2001; Maurer et al, 2004). Increased misuse of these compounds in the US has prompted the Drug Enforcement Administration (DEA) to invoke emergency Schedule I classification of BZP and TFMPP, making possession of these compounds a criminal offense (Department of Justice, 2002).

It is well established from preclinical findings that TFMPP is a non-selective 5-HT receptor agonist, with the drug exhibiting modest binding affinity $(\sim 100 \mathrm{nM})$ for $5-\mathrm{HT}_{1}$ and 5- $\mathrm{HT}_{2}$ receptor subtypes (Fuller, 1988; Hoyer, 1988). Similar to MDMA, however, TFMPP displays presynaptic actions that include stimulation of SERT-mediated 5-HT release from neurons, as demonstrated in vitro (Pettibone and Williams, 1984) and in vivo (Auerbach et al, 1991). There is limited information available on the molecular mechanism of BZP, but this drug elicits amphetamine-like behavioral effects in rodents (Jones et al, 1980) and humans (Bye et al, 1973). No scientific investigations regarding the neurobiology of BZP plus TFMPP (BZP/TFMPP) are available. Thus, the aim of the present study was to examine the effects of BZP and TFMPP on monoamine neurotransmission in rat brain. In particular, we compared the effects of MDMA, BZP, and TFMPP on transporter-mediated release of DA and 5 -HT using in vitro and in vivo neurochemical methods. Because BZP and TFMPP are reportedly coadministered by human drug users, we examined the effects of these agents alone and in combination.

\section{MATERIALS AND METHODS}

\section{Animals}

Male Sprague-Dawley rats weighing 300-350 g were singly housed (lights on: 0700-1900 h) with food and water freely available. Rats were maintained in facilities accredited by the American Association of the Accreditation of Labora-

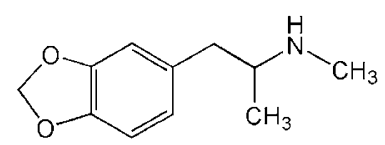

MDMA

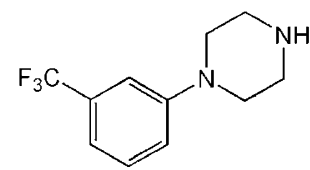

1-(m-Trifluoromethylphenyl)piperazine (TFMPP)

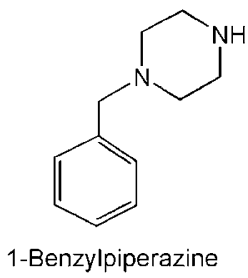

(BZP)

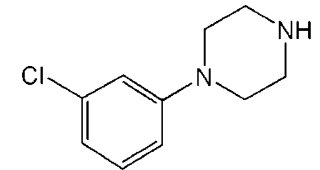

1-(m-Chlorophenyl)piperazine (mCPP)
Figure I Chemical structures of MDMA and the N-substituted piperazine analogs, BZP, TFMPP, and $\mathrm{mCPP}$. tory Animal Care, and the procedures described herein were carried out in accordance with the Animal Care and Use Committee of the National Institute on Drug Abuse (NIDA) Intramural Research Program (IRP).

\section{Drugs and Reagents}

(士)-3,4-Methylenedioxymethamphetamine $\mathrm{HCl}$ (MDMA) was generously provided by the NIDA Drug Supply Program, Rockville, MD. 1-Benzylpiperazine hydrochloride (BZP) and 1-( $m$-trifluoromethylphenyl)piperazine hydrochloride (TFMPP) were obtained from Research Triangle Institute, Research Triangle Park, NC. Sources of the reagents required for the in vitro release assays and the in vivo microdialysis methods have been previously reported (Baumann et al, 2001; Rothman et al, 2001).

\section{In Vitro Release Methods}

Transporter-mediated release assays were carried out as previously described with minor modifications (Rothman et al, 2001). Rats were killed by $\mathrm{CO}_{2}$ asphyxiation. Tissue from caudate (for DAT assay), or from whole brain minus cerebellum and caudate (for SERT assay), was homogenized in ice-cold $10 \%$ sucrose containing $1 \mu \mathrm{M}$ reserpine. For DAT-mediated release assays, $\left[{ }^{3} \mathrm{H}\right] 1$-methyl-4-phenylpyridinium $\left(\left[{ }^{3} \mathrm{H}\right] \mathrm{MPP}^{+}\right)$was used as the radiolabeled substrate; $100 \mathrm{nM}$ desipramine and $100 \mathrm{nM}$ citalopram were added to prevent uptake of $\left[{ }^{3} \mathrm{H}\right] \mathrm{MPP}^{+}$into NE and 5-HT nerves. For SERT-mediated release assays, $\left[{ }^{3} \mathrm{H}\right] 5-\mathrm{HT}$ was used as the radiolabeled substrate; $100 \mathrm{nM}$ nomifensine and $100 \mathrm{nM}$ GBR12935 were added to the sucrose solution to prevent uptake of $\left[{ }^{3} \mathrm{H}\right] 5-\mathrm{HT}$ into $\mathrm{NE}$ and DA nerve terminals. Synaptosomal preparations were incubated to steady state with $\left.5 \mathrm{nM} \mathrm{[}{ }^{3} \mathrm{H}\right] \mathrm{MPP}^{+}(60 \mathrm{~min})$ or $\left.5 \mathrm{nM} \mathrm{[}{ }^{3} \mathrm{H}\right] 5-\mathrm{HT}(60 \mathrm{~min})$ in Krebs-phosphate buffer ( $\mathrm{pH} 7.4)$, plus $1 \mu \mathrm{M}$ reserpine. Subsequently, $850 \mu \mathrm{l}$ of synaptosomes preloaded with $\left[{ }^{3} \mathrm{H}\right]$ ligand were added to polystyrene test tubes that contained $150 \mu \mathrm{l}$ of test drug in assay buffer plus $1 \mathrm{mg} / \mathrm{ml}$ BSA. After $5 \mathrm{~min}\left(\left[{ }^{3} \mathrm{H}\right] 5-\mathrm{HT}\right)$ or $30 \mathrm{~min}\left(\left[{ }^{3} \mathrm{H}\right] \mathrm{MPP}^{+}\right)$the release reaction was terminated by dilution with $4 \mathrm{ml}$ wash buffer followed by rapid vacuum filtration. The retained tritium was counted by a Topcount liquid scintillation counter (Perkin-Elmer, Downers Grove, IL). Dose-effect curves were generated for MDMA, BZP, and TFMPP by testing 8-10 concentrations of each drug in assays. Substrate reversal experiments were performed to verify that monoamine transporter sites were involved in the releasing properties of drugs. Specifically, GBR12909 $(10 \mathrm{nM})$ was used to antagonize DAT-mediated $\left[{ }^{3} \mathrm{H}\right] \mathrm{MPP}^{+}$ release, whereas fluoxetine $(10 \mathrm{nM})$ was used to antagonize SERT-mediated $\left[{ }^{3} \mathrm{H}\right] 5-\mathrm{HT}$ release.

\section{Surgical Procedures}

For microdialysis studies, rats received sodium pentobarbital $(60 \mathrm{mg} / \mathrm{kg}$, i.p.) for surgical anesthesia. Indwelling catheters made of Silastic Medical Grade tubing (Dow Corning, Midland, MI) were implanted into the right jugular vein to allow for i.v. drug administration. Intracerebral guide cannulae made of plastic (CMA 12, CMA/Microdialysis, Acton, MA) were implanted above the nucleus 
accumbens according to the following coordinates: $\mathrm{ML} \pm 1.7 \mathrm{~mm}$ and $\mathrm{AP}+1.6 \mathrm{~mm}$ from bregma, $\mathrm{DV}-6.0 \mathrm{~mm}$ from dura (Paxinos and Watson, 1986). The guide cannulae were secured to the skull using stainless-steel screws and dental acrylic. Animals were housed individually and allowed 7-10 days for recovery.

\section{In Vivo Microdialysis Methods}

Microdialysis sampling was carried out as previously described, with some modifications (Baumann et al, 2001). On the evening before an experiment, rats were moved to the testing room and briefly anesthetized with the ultra-short acting barbiturate, methohexital (10 mg/kg, i.v.). While anesthetized, a plastic collar was placed on each rat. Dialysis probes with $2 \times 0.5 \mathrm{~mm}$ exchange surface (CMA/12, CMA Microdialysis) were inserted into guide cannulae and extension tubes were attached to jugular catheters. Each rat was placed into its own activity field arena (Coulbourn Instruments, Allentown, PA) and connected to a tethering system that allowed motor activity within the arena. The microdialysis inflow and outflow tubing, as well as the catheter extension tubing, was connected to a fluid swivel (Instech Laboratories, Inc., Plymouth Meeting, PA). Probes were perfused in situ overnight with artificial cerebrospinal fluid containing $150.0 \mathrm{mM} \mathrm{Na}, 3.0 \mathrm{mM} \mathrm{K}, 1.4 \mathrm{mM} \mathrm{Ca}$, $0.8 \mathrm{mM} \mathrm{Mg}, 1.0 \mathrm{mM} \mathrm{P}$, and $155 \mathrm{mM} \mathrm{Cl}$ (Harvard Bioscience, Holliston, MA), pumped at a flowrate of $0.5 \mu \mathrm{l} / \mathrm{min}$. On the morning of the experiment, dialysate samples were collected at 20-min intervals. Samples were immediately assayed for DA and 5-HT by HPLC with electrochemical detection as described below. Once three stable baseline samples were obtained, drug treatments were administered. Microdialysis samples were collected throughout the postinjection period for $120 \mathrm{~min}$. At the end of the microdialysis experiments, rats were killed by $\mathrm{CO}_{2}$ asphyxiation, brains were removed from the skull and stored in $10 \%$ formalin. Brains were sectioned on a cryostat and mounted on glass slides. The placement of microdialysis probe tips within the nucleus accumbens was verified by visual inspection, and only rats with correct placements were included in the data analyses.

\section{Drug Injection Procedures}

Rats received two sequential i.v. drug injections on an ascending dose schedule: the first drug injection was given at time zero, followed by the second injection given $60 \mathrm{~min}$ later. The dose of MDMA, BZP, or TFMPP administered at the first injection (ie time zero) was the threshold dose producing significant elevations of extracellular DA or 5$\mathrm{HT}$, as determined by pilot experiments. The dose of drug for the second injection (ie $+60 \mathrm{~min}$ ) was 3 -times higher than the first dose. Because human drug users have reportedly ingested BZP and TFMPP simultaneously, we sought to examine the combined effects of these compounds in vivo. BZP and TFMPP were mixed at a 1:1 ratio and administered as single injection. Drugs were dissolved in $0.9 \% \mathrm{NaCl}$ immediately prior to injection, and doses are expressed as the salt.

\section{Analysis of DA and 5-HT in Microdialysates}

Aliquots of dialysate $(5 \mu \mathrm{l})$ were injected onto a microbore $\mathrm{C}_{18}$ column that was coupled to an amperometric detector (Model LC-4C, Bioanalytical Systems, Inc., West Lafayette, IN). A glassy carbon electrode was set at a potential of $+650 \mathrm{mV}$ relative to $\mathrm{Ag} / \mathrm{AgCl}$ reference. Mobile phase consisting of $150 \mathrm{mM}$ monochloroacetic acid, $150 \mathrm{mM}$ sodium hydroxide, $2.5 \mathrm{mM}$ sodium octanesulfonic acid, $250 \mu \mathrm{M}$ disodium EDTA, $6 \%$ methanol and $6 \%$ acetonitrile per liter of water (final $\mathrm{pH}=5.3$ ) was pumped at a flowrate of $60 \mu \mathrm{l} / \mathrm{min}$ using a syringe pump (Model 260D, ISCO, Lincoln NE, USA). Chromatographic data were acquired on-line and exported to a Millennium software system (Waters Associates, Milford, MA, USA) for peak amplification, integration, and analysis. Standards of DA and 5-HT were run daily before dialysate samples, and standard curves were linear over a wide range of concentrations (1-1000 pg). A monoamine standard mix containing NE, DA and 5-HT, and their respective acid metabolites, was injected before and after the experiment to insure validity of the constituent retention times. Peak heights of unknowns were compared to peak heights of standards, and the lower limit of assay sensitivity $(3 \times$ baseline noise) was $50 \mathrm{fg} /$ sample.

\section{Locomotor Measures}

During the overnight acclimation period and during microdialysis sampling, each rat was housed within a Plexiglass arena $(40 \mathrm{~cm}$ length, width and height) that was equipped with an automated activity monitoring system (Tru Scan, Coulbourn Instruments). A sensor ring lined with photobeams spaced $2.54 \mathrm{~cm}$ apart was positioned in the horizontal plane of the arena to allow for real-time monitoring of various motor parameters. Activity was monitored in 20-min bins, beginning $60 \mathrm{~min}$ before i.v. drug injections and continuing for $120 \mathrm{~min}$ thereafter. Ambulation and stereotypy were quantified separately; ambulation is defined as the total distance traveled in the horizontal plane (measured in $\mathrm{cm}$ traveled), whereas stereotypy is defined as total number of photobeam breaks less than \pm 1.5 beam spaces and back to the original point, that do not exceed $2 \mathrm{~s}$ apart (measured in number of movements).

\section{Data Analyses and Statistics}

For in vitro release experiments, $\mathrm{EC}_{50}$ values were calculated using the nonlinear least-squares curve-fitting program MLAB-PC (Civilized Software, Bethesda, MD) as described elsewhere (Rothman et al, 2001). F-tests were used to determine whether the effects of uptake blockers achieved statistical significance in the substrate reversal experiments. For in vivo microdialysis and locomotor activity experiments, raw data were evaluated by one-factor analysis of variance (ANOVA) with repeated measures. When significant F-values were obtained, Duncans' post hoc test was used to determine statistical significance between group means $(P<0.05)$. 


\section{RESULTS}

\section{Effects of Drugs on Release of $\left[{ }^{3} \mathrm{H}\right] \mathrm{MPP}^{+}$and $\left[{ }^{3} \mathrm{H}\right] 5-\mathrm{HT}$ In Vitro}

The data in Figure 2 show that MDMA (left panel) and BZP (right panel) produce dose-dependent efflux of preloaded $\left[{ }^{3} \mathrm{H}\right] \mathrm{MPP}^{+}$from synaptosomes. MDMA and BZP had $\mathrm{EC}_{50}$ values of $119 \pm 8$ and $175 \pm 13 \mathrm{nM}$, respectively, whereas TFMPP was inactive as a releaser of $\left[{ }^{3} \mathrm{H}\right] \mathrm{MPP}^{+}$at concentrations up to $10 \mu \mathrm{M}$. The DA uptake blocker GBR12909 (10 nM) significantly antagonized the release of $\mathrm{MPP}^{+}$produced by MDMA $(\mathrm{F}=180 ; P<0.0001)$ and BZP $(\mathrm{F}=123 ; P<0.0001)$, as indicated by the rightward shifts in the dose-effect curves. Thus, DAT proteins are involved in the $\mathrm{MPP}^{+}$-releasing capability of MDMA and BZP.

Figure 3 shows that MDMA (left panel) and TFMPP (right panel) produce dose-dependent efflux of preloaded $\left[{ }^{3} \mathrm{H}\right] 5$ HT from synaptosomes. MDMA and TFMPP displayed $\mathrm{EC}_{50}$ values of $58 \pm 6$ and $121 \pm 17 \mathrm{nM}$, respectively, whereas BZP was inactive as a releaser of $\left[{ }^{3} \mathrm{H}\right] 5-\mathrm{HT}$ at concentrations up to $10 \mu \mathrm{M}$. The 5 -HT uptake inhibitor fluoxetine $(10 \mathrm{nM})$ significantly antagonized 5-HT release produced by MDMA $(\mathrm{F}=17.9 ; P<0.001)$ and TFMPP $(\mathrm{F}=11.5 ; P<0.01)$, implicating SERT proteins in the mechanism of drug-induced release. Because we were interested in possible drug-drug interactions between BZP and TFMPP, these two analogs were coincubated at varying concentrations in release assays for $\left[{ }^{3} \mathrm{H}\right] 5-\mathrm{HT}$ and $\left[{ }^{3} \mathrm{H}\right] \mathrm{MPP}^{+}$. Importantly, BZP did not alter the 5-HT-releasing potency of TFMPP, and TFMPP did not affect the MPP ${ }^{+}$-releasing potency of BZP (data not shown).
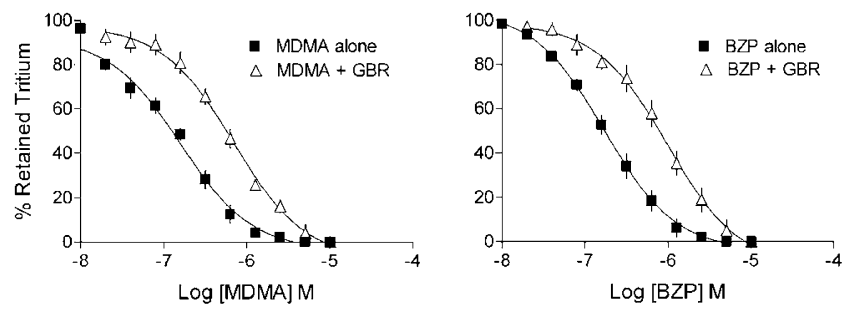

Figure 2 Dose-response effects of MDMA (left panel) and BZP (right panel) on the release of preloaded $\left.{ }^{3} \mathrm{H}\right] \mathrm{MPP}+$ from synaptosomes in vitro. Various concentrations of MDMA or BZP were incubated with or without the DA uptake blocker GBRI2909 (I 0 nM). Data are mean \pm SD for three separate experiments, each performed in triplicate.
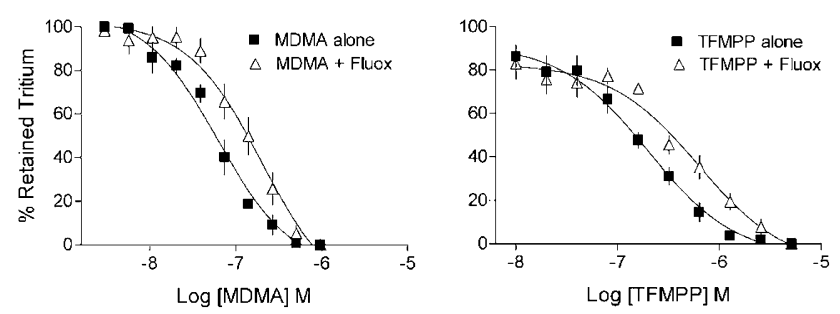

Figure 3 Dose-response effects of MDMA (left panel) and TFMPP (right panel) on the release of preloaded $\left[{ }^{3} \mathrm{H}\right] 5-\mathrm{HT}$ from synaptosomes in vitro. Various concentrations of MDMA or TFMPP were incubated with or without the 5-HT uptake blocker fluoxetine $(10 \mathrm{nM})$. Data are mean \pm SD for three experiments, each performed in triplicate.

\section{Effects of MDMA Administration In Vivo}

Figure 4 shows the effects of i.v. administration of MDMA on in vivo release of DA and 5-HT in rat nucleus accumbens. MDMA produced dose-related elevations in dialysate levels of DA $(\mathrm{F}=5.56 ; P<0.0001)$ and 5-HT $(\mathrm{F}=33.04 ; P<0.00001)$, but the effects of the drug on 5 -HT were always predominant. For example, at the $1.0 \mathrm{mg} /$ $\mathrm{kg}$ dose, MDMA caused a $150 \%$ increase in dialysate DA and a $750 \%$ increase in 5-HT. The MDMA-induced rise in extracellular DA and 5-HT was rapid and 'spikelike', consistent with the notion that MDMA is a substratetype monoamine releasing agent (Rothman and Baumann, 2002).

The data in Figure 5 illustrate the effects of MDMA on motor activity in rats undergoing microdialysis. MDMAtreated rats displayed significant increases in ambulation $(\mathrm{F}=8.02 ; \quad P<0.0001)$ and stereotypic movements $(\mathrm{F}=18.38 ; P<0.0001)$ that were dose-related. Specifically, bursts of forward locomotion were followed by brief periods of in-place stereotypic movements. Ambulation produced by MDMA was unique: animals appeared to crawl on their bellies with hind limbs splayed due to flattened body posture, and the path of forward locomotion was mostly confined to the perimeter of the arena (Gold et al, 1988). Stereotypic movements were predominately side-to-side head weaving in the horizontal plane, and forepaw treading (Spanos and Yamamoto, 1989).
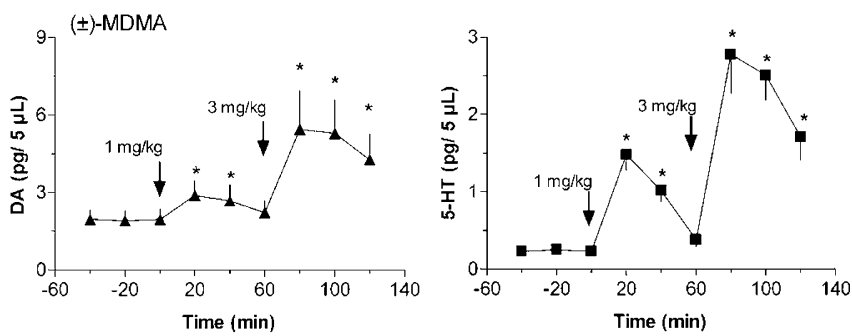

Figure 4 Effects of MDMA on concentrations of DA (left panel) and 5HT (right panel) in dialysate samples collected from rat nucleus accumbens in vivo. Rats received i.v. injections of I $\mathrm{mg} / \mathrm{kg}$ MDMA at time zero followed by $3 \mathrm{mg} / \mathrm{kg} 60 \mathrm{~min}$ later. Data are mean \pm SEM, expressed as pg/5 $\mu$ l sample for $N=7$ rats per group. $* P<0.05$ vs preinjection baseline, Duncan's multiple range test.
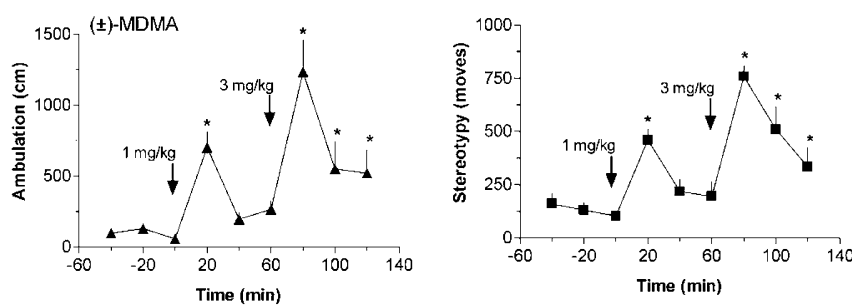

Figure 5 Ambulation (left panel) and stereotypy (right panel) produced by MDMA in rats undergoing in vivo microdialysis. Rats received i.v. injections of I mg/ $/ \mathrm{kg}$ MDMA at time zero followed by $3 \mathrm{mg} / \mathrm{kg} 60 \mathrm{~min}$ later. Data are mean \pm SEM, expressed as distance traveled in $\mathrm{cm}$ (ambulation) or number of repetitive movements (stereotypy) for $N=7$ rats per group. *P $<0.05$ vs preinjection baseline, Duncan's multiple range test. 


\section{Effects of BZP and TFMPP Administration In Vivo}

Figure 6 depicts the effects of i.v. administration of BZP on dialysate concentrations of DA and 5-HT in rat nucleus accumbens. BZP produced dose-related elevations in dialysate levels of DA $(\mathrm{F}=15.95 ; P<0.00001)$ and 5 -HT $(\mathrm{F}=5.12 ; P<0.0001)$, but the effects of the drug on DA were predominant. Specifically, BZP produced a significant rise in DA at the 3 and $10 \mathrm{mg} / \mathrm{kg}$ doses, whereas the drug affected 5-HT only at the highest dose. The elevations in DA produced by BZP were rapid and spike-like, consistent with the profile of a substrate-type DA releasing agent. It is noteworthy that BZP was about three-fold less potent than MDMA as a DA releaser in vivo, and much less potent as a 5-HT releaser. Figure 7 shows the effects of BZP on motor activity in rats undergoing microdialysis. BZP-treated rats displayed significant increases in ambulation $(\mathrm{F}=8.57$; $P<0.0001)$ and stereotypic movements $(\mathrm{F}=22.99$; $P<0.00001)$ that were dose-related. BZP-induced ambulation was characterized by continuous circling of the arena, interrupted by intense bouts of sniffing and rearing; these effects were especially apparent at the high dose. Stereotypic movements produced by BZP consisted mainly of headbobbing in the vertical plane, and repetitive sniffing.

As shown in Figure 8, TFMPP produced a significant increase in dialysate 5 - $\mathrm{HT}(\mathrm{F}=14.23 ; P<0.0001)$ but had no effect on dialysate $\mathrm{DA}(\mathrm{F}=0.79 ; P<0.625)$. The stimulatory effect of TFMPP on extracellular 5-HT release was less potent when compared to MDMA (compare Figures 4 and 8). Thus, it appears that TFMPP is a selective low-
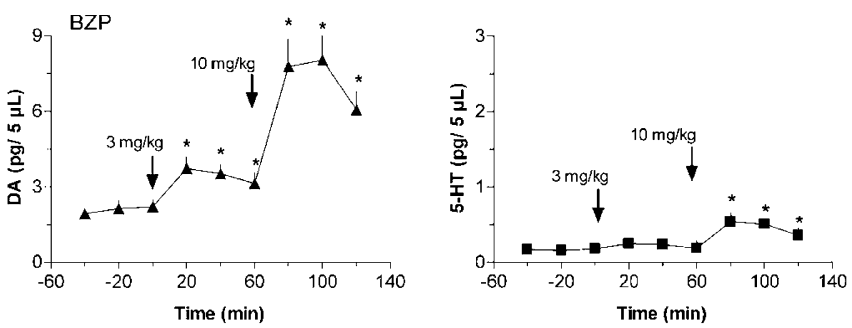

Figure 6 Effects of BZP on concentrations of DA (left panel) and 5-HT (right panel) in dialysate samples collected from rat nucleus accumbens in vivo. Rats received i.v. injections of $3 \mathrm{mg} / \mathrm{kg}$ BZP at time zero followed by $10 \mathrm{mg} / \mathrm{kg} 60 \mathrm{~min}$ later. Data are mean \pm SEM, expressed as $\mathrm{pg} / 5 \mu \mathrm{l}$ sample for $N=7$ rats per group. $* P<0.05$ vs preinjection baseline, Duncan's multiple range test.
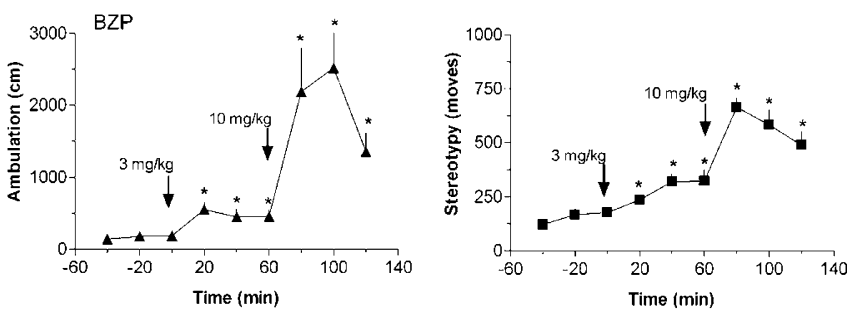

Figure 7 Ambulation (left panel) and stereotypy (right panel) produced by $B Z P$ in rats undergoing in vivo microdialysis. Rats received i.v. injections of $3 \mathrm{mg} / \mathrm{kg}$ BZP at time zero followed by $10 \mathrm{mg} / \mathrm{kg} 60 \mathrm{~min}$ later. Data are mean \pm SEM, expressed as distance traveled in $\mathrm{cm}$ (ambulation) or number of repetitive movements (stereotypy) for $N=7$ rats per group. $* P<0.05$ vs preinjection baseline, Duncan's multiple range test. potency 5-HT releasing agent. Figure 9 shows TFMPP had no significant effect on ambulation or stereotypy, even at high doses.

\section{Effects of BZP Plus TFMPP (BZP/TFMPP) Coadministration In Vivo}

The data depicted in Figure 10 show that administration of the BZP/TFMPP mixture produced significant dose-related increases in extracellular DA $(\mathrm{F}=24.87 ; P<0.00001)$ and 5 -HT $(\mathrm{F}=18.25 ; P<0.00001)$. At the $3 \mathrm{mg} / \mathrm{kg}$ dose, the effects of BZP/TFMPP on dialysate DA and 5-HT closely resembled the effects evoked by low-dose MDMA (compare Figures 4 and 10). At the $10 \mathrm{mg} / \mathrm{kg}$ dose, the combination evoked dramatic elevations in dialysate levels of DA and 5HT, with effects on DA being more robust. Table 1 summarizes the effects of high-dose BZP and TFMPP alone, and in combination, on dialysate DA and 5-HT. Note that actual elevations in extracellular DA produced by BZP/ TFMPP $(1286 \%$ of baseline) are much greater than the predicted additive effects of BZP plus TFMPP (531\% of baseline). In contrast, the effects of BZP/TFMPP on extracellular 5-HT ( $872 \%$ of baseline) are similar to the predicted additive value ( $980 \%$ of baseline). Thus, the magnitude of DA release produced by high-dose BZP/ TFMPP was far greater than the expected additive effects afforded by BZP and TFMPP alone, suggesting a synergistic effect on DA transmission when the drugs are combined.
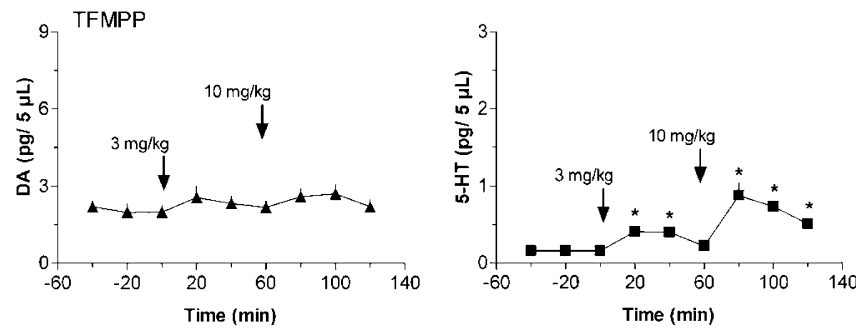

Figure 8 Effects of TFMPP on concentrations of DA (left panel) and 5HT (right panel) in dialysate samples collected from rat nucleus accumbens in vivo. Rats received i.v. injections of $3 \mathrm{mg} / \mathrm{kg}$ TFMPP at time zero followed by $10 \mathrm{mg} / \mathrm{kg} 60 \mathrm{~min}$ later. Data are mean \pm SEM, expressed as $\mathrm{pg} / 5 \mu$ sample for $N=6$ rats per group. ${ }^{*} P<0.05$ vs preinjection baseline, Duncan's multiple range test.
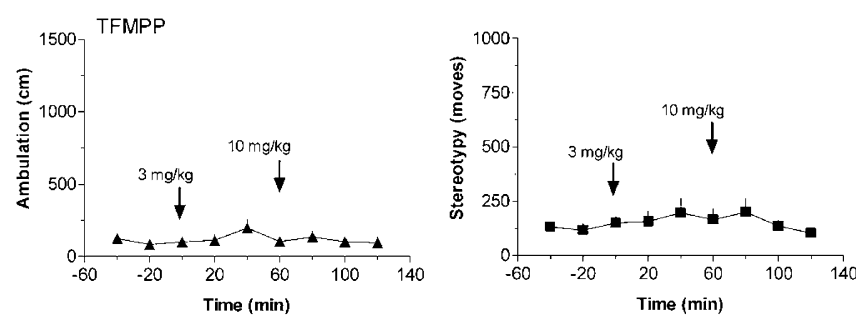

Figure 9 Ambulation (left panel) and stereotypy (right panel) produced by TFMPP in rats undergoing in vivo microdialysis. Rats received i.v. injections of $3 \mathrm{mg} / \mathrm{kg}$ TFMPP at time zero followed by $10 \mathrm{mg} / \mathrm{kg} 60 \mathrm{~min}$ later. Data are mean $\pm S E M$, expressed as distance traveled in $\mathrm{cm}$ (ambulation) or number of repetitive movements (stereotypy) for $N=6$ rats per group. 

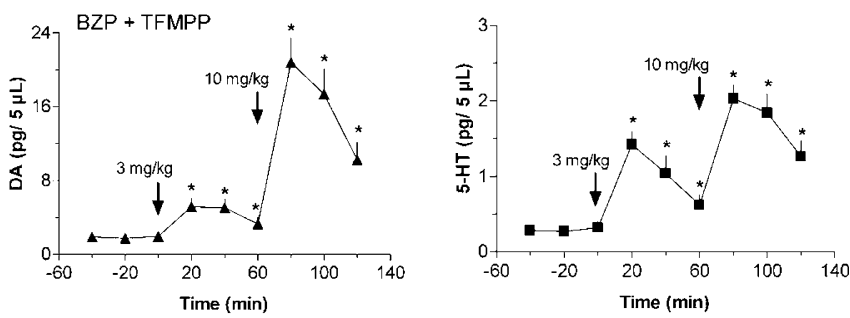

Figure 10 Effects of a 1:I mixture of BZP + TFMPP on DA (left panel) and 5-HT (right panel) in dialysate samples collected from rat nucleus accumbens in vivo. Rats received i.v. injections of $3 \mathrm{mg} / \mathrm{kg}$ BZP + TFMPP at time zero followed by $10 \mathrm{mg} / \mathrm{kg} 60 \mathrm{~min}$ later. Data are mean $\pm S E M$, expressed as $p g / 5 \mu \mathrm{l}$ sample for $N=7$ rats per group. $* P<0.05$ vs baseline, Duncan's multiple range test.
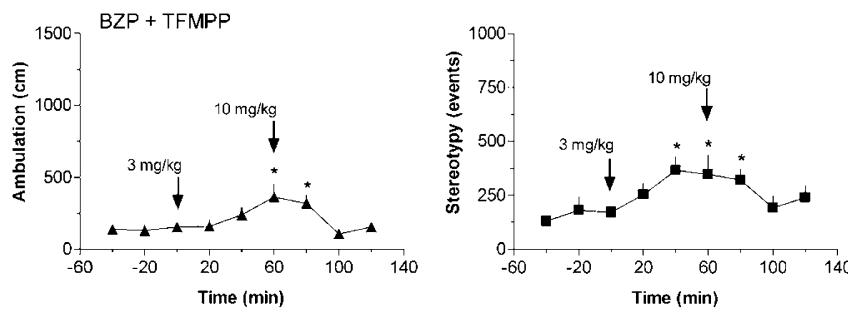

Figure II Ambulation (left panel) and stereotypy (right panel) produced by BZP + TFMPP in rats undergoing in vivo microdialysis. Rats received i.v. injections of $3 \mathrm{mg} / \mathrm{kg}$ BZP + TFMPP at time zero followed by $10 \mathrm{mg} / \mathrm{kg} 60 \mathrm{~min}$ later. Data are mean $\pm \mathrm{SEM}$, expressed as distance traveled in $\mathrm{cm}$ (ambulation) or number of repetitive movements (stereotypy) for $N=7$ rats per group. ${ }^{*} P<0.05$ vs preinjection baseline, Duncan's multiple range test.

Figure 11 depicts the effects of BZP/TFMPP on motor activity in rats undergoing microdialysis. BZP/ TFMPP did not elicit robust motor activity, even at doses that produce dramatic elevations in dialysate monoamine levels. The $3-\mathrm{mg} / \mathrm{kg}$ dose of BZP/TFMPP had weak stimulant actions, with significant increases in ambulation $(\mathrm{F}=3.83 ; \quad P<0.001)$ and stereotypy $(\mathrm{F}=2.63 ; P<0.01)$ occurring $40-60 \mathrm{~min}$ postinjection. Interestingly, at the higher dose, BZP/TFMPP suppressed motor activity, and several rats developed seizures and subsequent ataxia. Seizures produced by BZP/TFMPP were short-lived, and the affected rats appeared to recover fully by $60 \mathrm{~min}$ postinjection. Due to animal welfare concerns, further experiments using the $10 \mathrm{mg} / \mathrm{kg}$ dose of BZP/TFMPP were not performed.

\section{DISCUSSION}

A major aim of the present investigation was to examine the neurochemical effects of BZP and TFMPP, when administered alone and in combination. An additional goal was to compare the effects of these $\mathrm{N}$-substituted piperazines with the ring-substituted amphetamine, MDMA. Increasing evidence indicates that misuse of BZP and TFMPP is rising in the US and abroad (de Boer et al, 2001; Drug Enforcement Administration, 2001; Maurer et al, 2004; Wikstrom et al, 2004). In the US, for example, law enforcement officials from Federal, state and local jurisdic-
Table I Summary of In Vivo Neurochemical Effects of High-Dose MDMA, BZP, TFMPP, and BZP/TFMPP in Rat Nucleus Accumbens

Peak dialysate DA $^{\mathrm{a}}$ Peak dialysate $\mathbf{5}-\mathrm{HT}^{\mathrm{a}}$

\begin{tabular}{|c|c|c|}
\hline High-dose treatment & {$[\% \text { of baseline }]^{\mathbf{b}}$} & [\% of baseline $]^{\mathbf{b}}$ \\
\hline \multirow[t]{2}{*}{ MDMA, $3 \mathrm{mg} / \mathrm{kg}$} & $5.55 \pm 1.07 \mathrm{pg}$ & $2.92 \pm 0.31 \mathrm{pg}$ \\
\hline & {$[285 \pm 22 \%]$} & {$[1445 \pm 281 \%]$} \\
\hline \multirow[t]{2}{*}{ BZP alone, $10 \mathrm{mg} / \mathrm{kg}$} & $8.03 \pm 1.12 \mathrm{pg}$ & $0.54 \pm 0.10 \mathrm{pg}$ \\
\hline & {$[402 \pm 60 \%]$} & {$[352 \pm 64 \%]$} \\
\hline \multirow[t]{2}{*}{ TFMPP alone, $10 \mathrm{mg} / \mathrm{kg}$} & $2.60 \pm 0.37 \mathrm{pg}$ & $0.88 \pm 0.17 \mathrm{pg}$ \\
\hline & {$[129 \pm 18 \%]$} & {$[628 \pm 159 \%]$} \\
\hline BZP/TFMPP, $10 \mathrm{mg} / \mathrm{kg}$ & $20.76 \pm 2.67 p g$ & $2.03 \pm 0.18 \mathrm{pg}$ \\
\hline (actual measured value) & {$[1286 \pm 172 \%]$} & {$[872 \pm 163 \%]$} \\
\hline $\mathrm{BZP}+\mathrm{TFMPP}, 10 \mathrm{mg} / \mathrm{kg}$ & $10.63 \mathrm{pg}$ & $1.42 \mathrm{pg}$ \\
\hline (predicted additive effect) & {$[531 \%]$} & [980\%] \\
\hline
\end{tabular}

Neurochemical data are derived from results depicted in Figures 4, 6, 8 and 10, with specific reference to the high-dose administration conditions.

${ }^{a}$ Raw values for DA and 5-HT are mean \pm SEM for $N=6-7$ rats/group, expressed as $p g / 5 \mu$ l sample.

b\% Baseline values for DA and 5-HT are mean \pm SEM for $N=6-7$ rats/group, expressed as a percentage of three baseline samples collected prior to the first injection at time zero.

tions have reported a marked increase in the number of confiscated tablets containing BZP and/or TFMPP. Internet websites reveal personal accounts of drug users who have ingested various combinations of 'Legal $\mathrm{X}$ ' piperazine analogs, particularly BZP and TFMPP, in an attempt to reproduce the MDMA subjective experience (see Drug Enforcement Administration, 2001; Erowid piperazine vault, 2004). Although the extent of piperazine abuse is impossible to ascertain, the DEA has placed BZP and TFMPP into emergency Schedule I status based on the potential for imminent hazard to public safety (Department of Justice, 2002).

The present in vitro data confirm that MDMA is a monoamine-releasing agent that acts as a substrate for DATs and SERTs in nervous tissue (reviewed by Green $e t$ al, 2003). Our findings agree with the work of others who showed that MDMA evokes transporter-mediated release of $\left[{ }^{3} \mathrm{H}\right] \mathrm{DA}$ and $\left[{ }^{3} \mathrm{H}\right] 5-\mathrm{HT}$ from rat brain slices and synaptosomes (Nichols et al, 1982; Johnson et al, 1986; Schmidt et al, 1987; McKenna et al, 1991; Berger et al, 1992). In a side-by-side comparison with MDMA, we demonstrated that BZP is a releaser of $\left[{ }^{3} \mathrm{H}\right] \mathrm{MPP}^{+}$, whereas TFMPP is a releaser of $\left[{ }^{3} \mathrm{H}\right] 5-\mathrm{HT}$. Similar to MDMA, the in vitro releasing properties of BZP and TFMPP are mediated by substrate activity at DATs and SERTs, since low doses of selective transporter blockers can antagonize the effects of these piperazines (see Figures 2 and 3). It is noteworthy that BZP and TFMPP are somewhat less potent than MDMA with respect to stimulating $\left[{ }^{3} \mathrm{H}\right]$ monoamine release in vitro. To the best of our knowledge, the present findings with BZP are the first demonstration of DAT substrate activity for this compound. Our in vitro findings with TFMPP support previous data showing halogenated piperazines release endogenous 5 - HT from rat brain tissue at doses ranging from 0.1 to $10 \mu \mathrm{M}$ (Pettibone and Williams, 1984; Auerbach 
et al, 1990; Rothman and Baumann, 2002). Pettibone and Williams (1984) found that TFMPP and its chlorosubstituted analog, 1-( $m$-chlorophenyl)piperazine (mCPP, see Figure 1), stimulate 5 -HT release from hypothalamic slices by a mechanism involving SERTs but not calcium ions. Similarly, Auerbach et al (1990) reported that TFMPP evokes fluoxetine-reversible release of 5-HT from hippocampal slices, and this releasing action is not altered by 5 -HT receptor antagonists. Taken together, the in vitro data indicate that TFMPP and $\mathrm{MCPP}$ are potent SERT substrates capable of releasing endogenous stores of 5-HT from neurons, analogous to the effects of MDMA and other substituted amphetamines (Rothman and Baumann, 2002).

Our microdialysis data demonstrate that MDMA is a powerful releaser of DA and 5-HT in vivo, with effects on 5 -HT release being more robust (see Figure 4). The monoamine-releasing action of MDMA in rat nucleus accumbens mirrors the MDMA-induced rise in extracellular DA and 5-HT observed in rat prefrontal cortex and striatum (Yamamoto and Spanos, 1988; Gough et al, 1991; Nash and Brodkin, 1991; Gudelsky and Nash, 1996). Using our experimental paradigm, the lowest dose of MDMA capable of stimulating concurrent DA and 5 -HT release was $1 \mathrm{mg} / \mathrm{kg}$ i.v., a dose reported to maintain self-administration behavior in rats (Ratzenboeck et al, 2001; Schenk et al, 2003). At this dose of MDMA, dialysate levels of DA increased 1.5-fold above baseline whereas dialysate 5-HT increased 7.5-fold. Data from previous in vivo experiments show that MDMA increases extracellular levels of 5-HT in the brain by a mechanism dependent on SERT proteins (Gudelsky and Nash, 1996; Mechan et al, 2002). Microdialysis studies have further revealed that MDMA can increase extracellular levels of DA via multiple mechanisms. In rat striatum, MDMA increases dialysate DA by at least two distinct processes: (1) a tetrodotoxin-insensitive process involving substrate activity at DAT proteins (Nash and Brodkin, 1991; Shankaran et al, 1999), and (2) a tetrodotoxin-sensitive process involving activation of 5$\mathrm{HT}_{2 \mathrm{~A}}$ receptor sites by endogenous 5-HT (Schmidt et al, 1994; Gudelsky and Nash, 1996). Whether 5-HT $2 \mathrm{~A}$ receptor mechanisms influence MDMA-induced DA release in rat nucleus accumbens, or in other brain regions, is unknown and awaits further investigation.

Doses of i.v. MDMA that evoked monoamine release in our study produced locomotor activation similar to the effects of s.c. MDMA described by others (Gold et al, 1988; Spanos and Yamamoto, 1989; Callaway et al, 1990). Specifically, MDMA produced a complex spectrum of behaviors including: (1) forward locomotion confined mostly to the periphery of the arena (Gold et al, 1988) and (2) elements of the 5-HT behavioral syndrome such as flattened body posture, forepaw treading, and head weaving (Spanos and Yamamoto, 1989). The fact that MDMA causes greater effects on 5-HT release, as compared to DA release, suggests stimulation of 5 -HT transmission is a major factor mediating the unique behavioral effects of this drug (see Callaway et al, 1990; Bankson and Cunningham, 2001). MDMA-induced 5-HT release would be expected to simultaneously activate receptor populations throughout the neuraxis, and multiple 5-HT receptor subtypes have been implicated in the behavioral actions of MDMA. For example, investigations in rats have shown that $5-\mathrm{HT}_{1 \mathrm{~B}}$ and $5-\mathrm{HT}_{2 \mathrm{~A}}$ receptors facilitate locomotor effects of MDMA, while $5-\mathrm{HT}_{2 \mathrm{C}}$ receptors impede these effects (Kehne et al, 1996; Bankson and Cunningham, 2002; Fletcher et al, 2002). The behaviors produced by MDMA likely involve the summed activation of multiple receptor subtypes located in numerous brain regions.

Administration of $\mathrm{BZP}$ stimulated a parallel rise in extracellular DA and 5-HT in vivo, but effects on DA were always predominant (see Figure 6). The profile of BZPinduced increases in dialysate DA and 5-HT is reminiscent of the effects of methamphetamine (Baumann et al, 2002), though BZP is less potent. It seems surprising that BZP produces elevations in dialysate $5-\mathrm{HT}$ in vivo, since the drug was inactive when tested as a releaser of $\left[{ }^{3} \mathrm{H}\right] 5-\mathrm{HT}$ in vitro. However, we have noted inconsistencies between in vitro and in vivo effects of monoamine releasers in prior studies. Methamphetamine, for example, displays nearly 30-fold greater potency as a releaser of $\left[{ }^{3} \mathrm{H}\right] \mathrm{DA}$ vs $\left[{ }^{3} \mathrm{H}\right] 5-\mathrm{HT}$ in synaptosomes (Rothman et al, 2001), yet low i.v. doses of methamphetamine evoke comparable increases in dialysate DA and 5-HT in rat nucleus accumbens (Baumann et al, 2002). While we have no simple explanation for such discrepancies, the data serve to illustrate that estimates of drug potency and selectivity based on in vitro findings alone may not necessarily predict in vivo drug actions. BZP was a powerful locomotor stimulant that elicited dose-dependent increases in ambulation, sniffing, and head-bobbing, similar to the effects of amphetamines (Segal and Kuczenski, 1994). It is noteworthy that the amount of forward locomotion produced by BZP was much greater than locomotion produced by MDMA. Our behavioral findings with BZP support previous results demonstrating this drug has amphetamine-like properties in rats (Jones et al, 1980) and humans (Bye et al, 1973). Based on the predominant effects of BZP on extracellular DA, it appears that stimulation of DA transmission may underlie the ability of this drug to induce amphetamine-like ambulation and stereotypy (see Kelly and Iversen, 1976; Kuczenski and Segal, 1994). The role of DA receptor subtypes in mediating behavioral effects of BZP is unexplored and warrants further study.

The present microdialysis findings with TFMPP show that this drug causes elevations in extracellular 5-HT in vivo, consistent with the in vitro findings (see Figure 8). Importantly, TFMPP is at least three-fold less potent than MDMA in its ability to stimulate release of endogenous 5-HT. TFMPP also appears less efficacious than MDMA, since the drug failed to produce large elevations in dialysate 5 -HT, even at high doses. Our microdialysis results agree with those of Auerbach et al (1991), who showed i.p. administration of TFMPP produces dose-related elevations in dialysate $5-\mathrm{HT}$ in rat diencephalon. We have used in vivo microdialysis in previous studies to demonstrate that $\mathrm{mCPP}$ stimulates release of $5-\mathrm{HT}$ in rat nucleus accumbens via a SERT-mediated process, analogous to the prototypical 5-HT releaser fenfluramine (Baumann et al, 1993, 2001). Eriksson et al (1999) reported that 5-HT release evoked by mCPP is blocked by 5 -HT uptake inhibitors but not by tetrodotoxin, suggesting the in vivo releasing effect of halogenated piperazines is not impulse-dependent. In contrast to the behavioral effects of BZP, TFMPP is not a locomotor 
stimulant. TFMPP did not alter motor activity at either dose tested, despite significant elevations in extracellular 5-HT in the nucleus accumbens. These results suggest that stimulation of SERT-mediated 5-HT release alone (ie in the absence of concurrent DA release) may not be sufficient to produce robust motor activation. We have shown that fenfluramine and chlorphentermine are relatively selective $5-\mathrm{HT}$ releasers in vivo, and these drugs do not produce locomotor stimulation (Baumann et al, 2000; Rothman and Baumann, 2000). Alternatively, the direct postsynaptic receptor actions of TFMPP may serve to inhibit behavior. It is known that TFMPP decreases spontaneous activity in rats exposed to a novel environment (Lucki et al, 1989), and such hypomotility is mediated via activation of $5-\mathrm{HT}_{2 \mathrm{C}}$ receptors. It is feasible that TFMPP did not decrease motor activity in our experiments because rats were already habituated to housing conditions with an overnight acclimation period.

The direct 5-HT receptor actions of TFMPP, and possibly BZP, must be considered when addressing the mechanism of action of these drugs. It is well accepted that TFMPP is a receptor agonist that displays significant affinity for multiple 5-HT receptor subtypes (Fuller, 1988; Hoyer, 1988; Schoeffter and Hoyer, 1989; see TFMPP receptor binding database, 2004). Accordingly, within the context of the present study, a fundamental question arises: What is the relative role of presynaptic $v s$ postsynaptic mechanisms in mediating the in vivo pharmacological actions of TFMPP? Our in vitro findings show that TFMPP releases $\left[{ }^{3} \mathrm{H}\right] 5-\mathrm{HT}$ from synaptosomes with an $\mathrm{EC}_{50}=121 \mathrm{nM}$ (see Figure 3), and this value is similar to the releasing potency of prototypical amphetamine-type 5-HT releasers such as MDMA $\left(\mathrm{EC}_{50}=58 \mathrm{nM}\right.$; present study) and fenfluramine $\left(\mathrm{EC}_{50}=79 \mathrm{nM}\right.$; Rothman and Baumann, 2002). Table 2 summarizes the affinities of TFMPP for various $5-\mathrm{HT}_{1}$ and $5-\mathrm{HT}_{2}$ receptor subtypes. Based on the release data and receptor binding data shown in Table 2 , it seems probable that TFMPP interacts with multiple 5-HT receptor subtypes and presynaptic SERT sites over the same concentration range in vivo. Interestingly, TFMPP and its analog $\mathrm{mCPP}$ are full agonists at $5-\mathrm{HT}_{2 \mathrm{C}}$ receptors, whereas these drugs act as weak partial agonists or antagonists at $5-\mathrm{HT}_{2 \mathrm{~A}}$ receptors (Conn and Sanders-Bush, 1987; Schoeffter and Hoyer, 1989; Grotewiel et al, 1994; Berg et al, 1998). Thus, TFMPP displays a novel pharmacology that includes: (1) full agonist activity at multiple 5-HT receptors, (2) partial agonist or antagonist activity at $5-\mathrm{HT}_{2 \mathrm{~A}}$ receptors, and (3) SERT-mediated 5-HT releasing activity. To the best of our knowledge, the direct receptor actions of BZP have not been examined.

Coadministration of BZP and TFMPP evoked dramatic dose-related increases in extracellular DA and 5-HT in the nucleus accumbens (Figure 10). At the low dose of BZP/ TFMPP ( $3 \mathrm{mg} / \mathrm{kg}$, i.v.), the drug mixture produced simultaneous release of DA and 5-HT that was qualitatively and quantitatively similar to the neurochemical effects produced by low-dose MDMA (compare the data in Figures 4 and 10). It seems feasible that monoamine-releasing properties of BZP/TFMPP could be involved with the reported MDMAlike psychoactive effects of this drug combination, thereby contributing to the evolving misuse of these piperazines (Drug Enforcement Administration, 2001; Department of Justice, 2002; Erowid piperazine vault, 2004; Maurer et al, 2004). In contrast to MDMA, low-dose BZP/TFMPP did not elicit robust locomotor stimulation. Consequently, there are significant differences between substituted piperazines and MDMA with respect to motor activity, and this may be attributable to direct postsynaptic actions of piperazine compounds. As mentioned already, TFMPP inhibits spontaneous locomotor activity via $5-\mathrm{HT}_{2 \mathrm{C}}$ receptor mechanisms. It is tempting to speculate that partial agonist or antagonist activity of TFMPP at $5-\mathrm{HT}_{2 \mathrm{~A}}$ receptors, coupled with full agonist activity at $5-\mathrm{HT}_{2 \mathrm{C}}$ receptors, could induce powerful inhibition of the motor-stimulant properties of BZP. Consistent with this notion, the selective $5-\mathrm{HT}_{2 \mathrm{~A}}$ antagonist MDL 100,907 reduces hyperactivity elicited by indirect DA agonists like amphetamine and cocaine (Moser et al, 1996; O'Neill et al, 1999). Similarly, selective 5- $\mathrm{HT}_{2 \mathrm{C}}$ agonists inhibit cocaine-induced motor stimulation (Grottick et al, 2000; Filip and Cunningham, 2003).

At the high dose of BZP/TFMPP $(10 \mathrm{mg} / \mathrm{kg}$, i.v. $)$, extracellular DA was elevated to a greater extent than the summed effects of BZP and TFMPP alone, suggesting a synergistic effect on DA transmission when the drugs are combined (see Table 1). In contrast, the rise in extracellular 5-HT produced by BZP/TFMPP was similar to the additive effects of BZP plus TFMPP. Several rats receiving the highdose combination developed seizures and subsequent ataxia. Although the seizures produced by BZP/TFMPP were short-lived and rats recovered completely, we did not investigate this phenomenon further due to animal welfare

Table 2 Relative Potency of TFMPP at 5-HT Receptor Subtypes and Monoamine Transporters in Brain Tissue

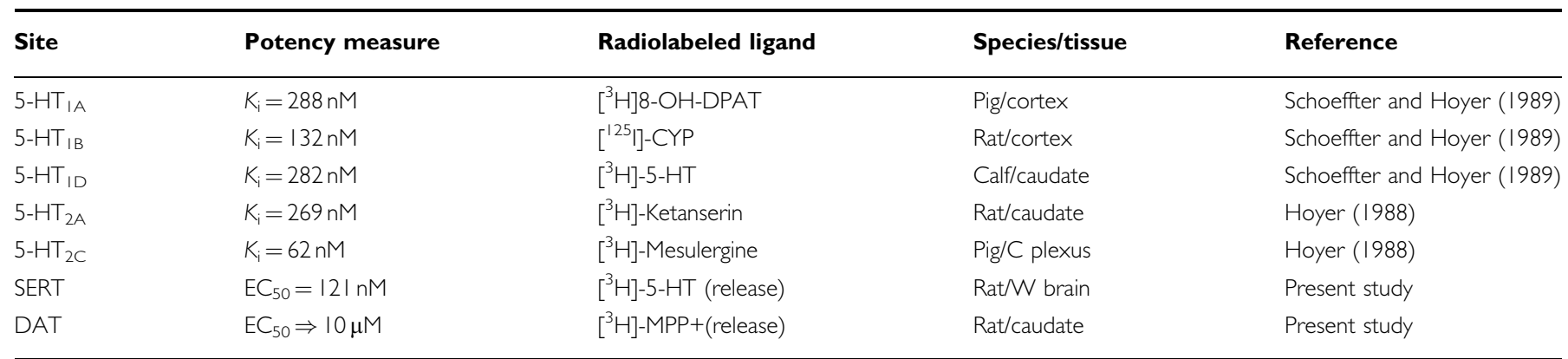

Potency measures for 5-HT receptor subtypes are taken from the literature as indicated, whereas measures for monoamine transporters are taken from release data shown in Figures 2 and 3. 
concerns. When BZP and TFMPP were incubated together during in vitro release assays, BZP did not alter ability of TFMPP to release $\left[{ }^{3} \mathrm{H}\right] 5-\mathrm{HT}$, and TFMPP did not alter the ability of BZP to release $\left[{ }^{3} \mathrm{H}\right] \mathrm{MPP}+$ (data not shown). Thus, it appears that interactions of BZP and TFMPP with monoamine transporters cannot explain synergistic effects of the combination, and any number of mechanisms may underlie the apparent drug-drug synergism. One possibility is that large elevations in extracellular 5 -HT produced by BZP/TFMPP might lead to facilitation of DA transmission (see Kuroki et al, 2003; Yamamoto et al, 1995). As mentioned previously, activation of $5-\mathrm{HT}_{2 \mathrm{~A}}$ receptors by endogenous 5-HT contributes to MDMA-induced increases in extracellular DA (Schmidt et al, 1994; Gudelsky and Nash, 1996). Furthermore, perfusion of 5-HT directly into the rat striatum or nucleus accumbens evokes marked elevations in extracellular DA (Benloucif and Galloway, 1991; Parsons and Justice, 1993). Nonetheless, several factors argue against the hypothesis of 5-HT facilitation of DA release with regard to the effects of BZP/TFMPP. First, as shown in Table 1, high-dose BZP/TFMPP produced a smaller rise in dialysate 5 -HT $(872 \%)$ when compared to high-dose MDMA (1445\%), yet BZP/TFMPP increased extracellular DA levels about four-fold more than MDMA. We have shown previously that certain 5-HT-releasing agents are capable of elevating dialysate 5 -HT levels more than 10-fold above baseline without any change in dialysate DA (Baumann et al, 2000, 2001). Such findings demonstrate a clear dissociation between increases in extraneuronal 5-HT and DA in rat nucleus accumbens. Second, the postsynaptic receptor profile of TFMPP, particularly $5-\mathrm{HT}_{2 \mathrm{~A}}$ antagonist activity and $5-\mathrm{HT}_{2 \mathrm{C}}$ agonist activity, is consistent with inhibition of DA transmission rather than facilitation (Di Matteo et al, 2000; Porras et al, 2002). It seems possible that high-dose BZP/TFMPP might enhance extracellular DA by blocking the activity of monoamine oxidase or catechol$\mathrm{O}$-methyl transferase, but these mechanisms have not been examined. Administration of high-dose BZP/TFMPP could overwhelm the ability of the organism to dispose of these drugs, causing elevated drug levels to accumulate in tissues, including the brain. Under these circumstances, monoaminergic and nonmonoaminergic processes might cause the development of seizures. Further work is necessary to determine the precise mechanism(s) underlying the apparent synergism between BZP and TFMPP.

In conclusion, the present findings show that BZP and TFMPP are capable of releasing DA and 5-HT from neurons via mechanisms dependent upon DATs and SERTs, respectively. The monoamine-releasing properties of piperazine analogs have been consistently demonstrated using in vitro and in vivo methods. The ability of the BZP/TFMPP combination to produce simultaneous elevations in extracellular DA and 5-HT in the nucleus accumbens mimics the known molecular mechanism of MDMA. Thus, we suspect that stimulatory effects of BZP/TFMPP on monoamine release might underlie the evolving misuse of these agents in humans. On the other hand, direct postsynaptic receptor actions of TFMPP undoubtedly contribute to the in vivo pharmacology of the BZP/TFMPP mixture, resulting in behavioral effects that could be different from those produced by MDMA. Perhaps the most striking findings reported here are the apparent drug-drug synergism and adverse behavioral effects (ie seizures) associated with highdose administration of BZP/TFMPP. The seizures caused by BZP/TFMPP occurred after a dose that is just three-fold greater than the threshold dose for monoamine-releasing activity, indicating a narrow window of safety. Collectively, our findings suggest the potential for dangerous consequences if human drug users experiment with ingesting BZP and TFMPP in combination.

\section{REFERENCES}

Auerbach SB, Kamalakannan N, Rutter JJ (1990). TFMPP and RU24969 enhance serotonin release from rat hippocampus. Eur J Pharmacol 190: 51-57.

Auerbach SB, Rutter JJ, Juliano PJ (1991). Substituted piperazine and indole compounds increase extracellular serotonin in rat diencephalon as determined by in vivo microdialysis. Neuropharmacology 30: 307-311.

Bankson MG, Cunningham KA (2001). 3,4-Methylenedioxymethamphetamine (MDMA) as a unique model of serotonin receptor function and serotonin-dopamine interactions. J Pharmacol Exp Ther 297: 846-852.

Bankson MG, Cunningham KA (2002). Pharmacological studies of the acute effects of (+)-3,4-methylenedioxymethamphetamine on locomotor activity: role of $5-\mathrm{HT}_{1 \mathrm{~B} / 1 \mathrm{D}}$ and $5-\mathrm{HT}_{2}$ receptors. Neuropsychopharmacology 26: 40-52.

Baumann MH, Ayestas MA, Dersch CM, Brockington A, Rice KC, Rothman RB (2000). Effects of phentermine and fenfluramine on extracellular dopamine and serotonin in rat nucleus accumbens: therapeutic implications. Synapse 36: 102-113.

Baumann MH, Ayestas MA, Dersch CM, Rothman RB (2001). 1-( $m$-Chlorophenyl)piperazine $(\mathrm{mCPP})$ dissociates in vivo serotonin release from long-term serotonin depletion. Neuropsychopharmacology 24: 492-501.

Baumann MH, Ayestas MA, Sharpe LG, Lewis DB, Rice KC, Rothman RB (2002). Persistent antagonism of methamphetamine-induced dopamine release in rats pretreated with GBR12909 decanoate. J Pharmacol Exp Ther 301: 11901197.

Baumann MH, Rutter JJ, Auerbach SB (1993). Intravenous administration of the serotonin agonist $m$-chlorophenylpiperazine $(\mathrm{mCPP})$ increases extracellular serotonin in the diencephalon of awake rats. Neuropharmacology 32: 1381-1386.

Benloucif S, Galloway MP (1991). Facilitation of dopamine release in vivo by serotonin agonists: studies with microdialysis. Eur J Pharmacol 200: 1-8.

Berg KA, Maayani S, Goldfarb J, Scaramellini C, Leff P, Clarke WP (1998). Effector pathway-dependent relative efficacy at serotonin type 2A and 2C receptors: evidence for agonist-directed trafficking of receptor stimulus. Mol Pharmacol 54: 94-104.

Berger UV, Gu XF, Azmitia EC (1992). The substituted amphetamines 3,4-methylenedioxymethamphetamine, methamphetamine, $p$-chloroamphetamine, and fenfluramine induce 5-hydroxytryptamine release via a common mechanism blocked by fluoxetine and cocaine. Eur J Pharmacol 215: 153-160.

Bye C, Munro-Faure AD, Peck AW, Young PA (1973). A comparison of the effects of 1-benzylpiperazine and dexamphetamine on human performance tests. Eur J Clin Pharmacol 6: 163-169.

Callaway CW, Wing LL, Geyer MA (1990). Serotonin release contributes to the locomotor stimulant effects of 3,4-methylenedioxymethamphetamine in rats. J Pharmacol Exp Ther 254: 456-463.

Conn PJ, Sanders-Bush E (1987). Relative efficacies of piperazines at the phosphoinositide hydrolysis-linked serotonergic (5-HT-2 and 5-HT-1c) receptors. J Pharmacol Exp Ther 242: 552-557. 
de Boer D, Bosman IJ, Hidvegi E, Manzoni C, Benko AA, dos Reys LJ et al (2001). Piperazine-like compounds: a new group of designer drugs-of-abuse on the European market. Forensic Sci Int 121: 47-56.

Department of Justice (2002). Schedules of controlled substances: temporary placement of benzylpiperazine and trifluoromethylphenylpiperazine into schedule I. http://www.deadiversion. usdoj.gov/fed_regs/sched_actions/2002.

Di Matteo V, Di Giovanni G, Di Mascio M, Esposito E (2000). Biochemical and electrophysiological evidence that Ro 60-0175 inhibits mesolimbic dopaminergic function through serotonin 2c receptors. Brain Res 865: 85-90.

Drug Enforcement Administration (2001). Drug intelligence brief. BZP and TFMPP: chemicals used to mimic MDMA's effects. http://www.dea.gov/pubs/intel/02005/02005.html.

Eriksson E, Engberg G, Bing O, Nissbrandt H (1999). Effects of mCPP on extracellular concentrations of serotonin and dopamine in rat brain. Neuropsychopharmacology 20: 287-296.

Erowid piperazine vault (2004). Erowid experience vaults: piperazine reports. http://www.erowid.org/chemicals/piperazines.

Filip M, Cunningham KA (2003). Hyperlocomotive and discriminative stimulus effects of cocaine are under the control of serotonin-2C $\left(5-\mathrm{HT}_{2 \mathrm{C}}\right)$ receptors in rat prefrontal cortex. J Pharmacol Exp Ther 306: 734-743.

Fletcher PJ, Korth KM, Robinson SR, Baker GB (2002). Multiple $5-\mathrm{HT}$ receptors are involved in the effects of acute MDMA treatment: studies on locomotor activity and responding for conditioned reinforcement. Psychopharmacology 162: 282-291.

Fuller RW (1988). 1-Phenylpiperazines and related compounds as centrally acting serotonin agonists. In: Rech RH, Gudelsky GA (eds). 5-HT Agonists as Psychoactive Drugs. NPP Books: Ann Arbor, MI. pp 35-59.

Gold LH, Koob GF, Geyer MA (1988). Stimulant and hallucinogenic behavioral profiles of 3,4-methylenedioxymethamphetamine and $\mathrm{N}$-ethyl-3,4-methylenedioxyamphetamine in rats. $J$ Pharmacol Exp Ther 247: 547-555.

Gough B, Ali SF, Slikker W, Holson RR (1991). Acute effects of 3,4methylenedioxymethamphetamine (MDMA) on monoamines in rat caudate. Pharmacol Biochem Behav 39: 619-623.

Green AR, Mechan AO, Elliott JM, O'Shea E, Colado MI (2003). The pharmacology and clinical pharmacology of 3,4-methylenedioxy methamphetamine (MDMA, 'Ecstasy'). Pharmacol Rev 55: 463-508.

Grotewiel MS, Chu H, Sanders-Bush E (1994). m-Chlorophenylpiperazine and m-trifluoromethylphenylpiperazine are partial agonists at cloned 5- $\mathrm{HT}_{2 \mathrm{~A}}$ receptors expressed in fibroblasts. J Pharmacol Exp Ther 271: 1122-1126.

Grottick AJ, Fletcher PJ, Higgins GA (2000). Studies to investigate the role of $5-\mathrm{HT}_{2 \mathrm{C}}$ receptors on cocaine- and food-maintained behavior. J Pharmacol Exp Ther 295: 1183-1191.

Gudelsky GA, Nash JF (1996). Carrier-mediated release of serotonin by 3,4-methylenedioxymethamphetamine: implications for serotonin-dopamine interactions. J Neurochem 66: 243-249.

Hoyer D (1988). Functional correlates of serotonin 5-HT1 recognition sites. J Recept Res 8: 59-81.

Johnson MP, Hoffman AJ, Nichols DE (1986). Effects of enantiomers of MDA, MDMA and related analogues on $\left[{ }^{3} \mathrm{H}\right]$ serotonin and $\left[{ }^{3} \mathrm{H}\right]$ dopamine release from superfused brain slices. Eur J Pharmacol 132: 269-276.

Jones CN, Howard JL, McBennett ST (1980). Stimulus properties of antidepressants in the rat. Psychopharmacology 67: 111-118.

Kehne JH, Kettler HJ, McCloskey TC, Sullivan CK, Dudley MW, Schmidt CJ (1996). Effects of the selective 5- $\mathrm{HT}_{2 \mathrm{~A}}$ receptor antagonist MDL 100,907 on MDMA-induced locomotor stimulation in rats. Neuropsychopharmacology 15: 116-124.

Kelly PH, Iversen SD (1976). Selective 6OHDA-induced destruction of mesolimbic dopamine neurons: abolition of psychosti- mulant-induced locomotor activity in rats. Eur J Pharmacol 40: $45-56$.

Kuczenski R, Segal DS (1994). Neurochemistry of amphetamine. In: Cho AK, Segal DS (eds). Amphetamine and its AnalogsPsychopharmacology, Toxicity and Abuse. Academic Press: San Diego, CA. pp 81-113.

Kuroki T, Meltzer HY, Ichikawa J (2003). 5- $\mathrm{HT}_{2 \mathrm{~A}}$ receptor stimulation by DOI, a $5-\mathrm{HT}_{2 \mathrm{~A} / 2 \mathrm{C}}$ receptor agonist, potentiates amphetamine-induced dopamine release in rat prefrontal cortex and nucleus accumbens. Brain Res 972: 216-221.

Landry MJ (2002). MDMA: a review of epidemiologic data. J Psychoactive Drugs 34: 163-169.

Liechti ME, Vollenweider FX (2001). Which neuroreceptors mediate the subjective effects of MDMA in humans? A summary of mechanistic studies. Hum Psychopharmacol 16: 589-598.

Lucki I, Ward HR, Frazer A (1989). Effect of 1-( $m$-chlorophenyl)piperazine and 1-(m-trifluoromethylphenyl)piperazine on locomotor activity. J Pharmacol Exp Ther 249: 155-164.

Lyles J, Cadet JL (2003). Methylenedioxymethamphetamine (MDMA, Ecstasy) neurotoxicity: cellular and molecular mechanisms. Brain Res Rev 42: 155-168.

Maurer HH, Kraemer T, Springer D, Staack RF (2004). Chemistry, pharmacology, toxicology, and hepatic metabolism of designer drugs of the amphetamine (ecstasy) piperazine, and pyrrolinidophenone types: a synopsis. Ther Drug Monitor 26: 127-132.

McKenna DJ, Guan XM, Shulgin AT (1991). 3,4-Methylenedioxyamphetamine (MDA) analogues exhibit differential effects on synaptosomal release of ${ }^{3} \mathrm{H}$-dopamine and ${ }^{3} \mathrm{H}-5$-hydroxytryptamine. Pharmacol Biochem Behav 38: 505-512.

Mechan AO, Esteban B, O'Shea E, Elliott JM, Colado MI, Green AR (2002). The pharmacology of the acute hyperthermic response that follows administration of 3,4-methylenedioxymethamphetamine (MDMA, 'Ecstasy') to rats. Br J Pharmacol 135: 170-180.

Morgan MJ (2000). Ecstasy (MDMA): a review of its possible persistent psychological effects. Psychopharmacology 152: 230-248.

Moser PC, Moran PM, Frank RA, Kehne JH (1996). Reversal of amphetamine-induced behaviours by MDL 100,907, a selective 5- $\mathrm{HT}_{2 \mathrm{~A}}$ antagonist. Behav Brain Res 73: 163-167.

Nash JF, Brodkin J (1991). Microdialysis studies on 3,4-methylenedioxymethamphemiane-induced dopamine release: effect of dopamine uptake inhibitors. J Pharmacol Exp Ther 259: $820-825$.

Nichols DE, Lloyd DH, Hoffman AJ, Nichols MB, Yim GK (1982). Effects of certain hallucinogenic amphetamine analogues on the release of $\left[{ }^{3} \mathrm{H}\right]$ serotonin from rat brain synaptosomes. $\mathrm{J} \mathrm{Med}$ Chem 25: 530-535.

O'Neill MF, Heron-Maxwell CL, Shaw G (1999). 5-HT2 receptor antagonism reduces hyperactivity induced by amphetamine, cocaine, and MK-801 but not the D1 agonist C-APB. Pharmacol Biochem Behav 63: 237-243.

Parrott AC (2002). Recreational Ecstasy/MDMA, the serotonin syndrome, and serotonergic neurotoxicity. Pharmacol Biochem Behav 71: 837-844.

Parsons LH, Justice Jr JB (1993). Perfusate serotonin increases extracellular dopamine in the nucleus accumbens as measured by in vivo microdialysis. Brain Res 606: 195-199.

Paxinos G, Watson C (1986). The Rat Brain in Stereotaxic Coordiantes. Academic Press: New York.

Pettibone DJ, Williams M (1984). Serotonin-releasing effects of substituted piperazines in vitro. Biochem Pharmacol 33: 1531-1535.

Porras G, Di Matteo V, Fracasso C, Lucas G, De Deurwaerdere P, Caccia $\mathrm{S}$ et al (2002). 5- $\mathrm{HT}_{2 \mathrm{~A}}$ and $5-\mathrm{HT}_{2 \mathrm{C} / 2 \mathrm{~B}}$ receptor subtypes modulate dopamine release in vivo by amphetamine and morphine in both rat nucleus accumbens and striatum. Neuropsychopharmacology 26: 311-324. 
Ratzenboeck E, Saria A, Kriechbaum N, Zernig G (2001). Reinforcing effects of MDMA ('ecstasy') in drug-naïve and cocaine-trained rats. Pharmacology 62: 138-144.

Rothman RB, Baumann MH (2000). Neurochemical mechanisms of phentermine and fenfluramine: therapeutic and adverse effects. Drug Dev Res 51: 52-65.

Rothman RB, Baumann MH (2002). Therapeutic and adverse actions of serotonin transporter substrates. Pharmacol Ther 95: 73-88.

Rothman RB, Baumann MH, Dersch CM, Romero DV, Rice KC, Carroll FI et al (2001). Amphetamine-type central nervous system stimulants release norepinephrine more potently than they release dopamine and serotonin. Synapse 39: 32-41.

Schenk S, Gittings D, Johnstone M, Daniela E (2003). Development, maintenance, and temporal pattern of self-administration maintained by ecstasy (MDMA) in rats. Psychopharmacology 169: 21-27.

Schmidt CJ, Levin JA, Lovenburg W (1987). In vitro and in vivo neurochemical effects of methylenedioxymethamphetamine on striatal monoaminergic systems in the rat. Biochem Pharmacol 36: 747-755.

Schmidt CJ, Sullivan CK, Fadayel GM (1994). Blockade of striatal 5-hydroxytryptamine2 receptors reduces the increase in extracellular concentrations of dopamine produced by the amphetamine analog, 3,4-methylenedioxymethamphetamine. J Neurochem 62: 1382-1389.

Shankaran M, Yamamoto BK, Gudelsky GA (1999). Mazindol attenuates the 3,4-methylenedioxymethamphetamine-induced formation of hydroxyl radicals and long-term depletion of serotonin in the striatum. J Neurochem 72: 2516-2522.
Schoeffter P, Hoyer D (1989). Interaction of arylpiperazines with 5HT1A, 5-HT1B, 5-HT1C and 5-HT1D receptors: do discriminatory 5-HT1B receptors ligands exist? Naunyn Schmiedebergs Arch Pharmacol 339: 675-683.

Segal DS, Kuczenski R (1994). Behavioral pharmacology of amphetamine. In: Cho AK, Segal DS (eds). Amphetamine and its Analogs-Psychopharmacology, Toxicity and Abuse. Academic Press: San Diego, CA. pp 115-150.

Spanos LJ, Yamamoto BK (1989). Acute and subchronic effects of methylenedioxymethamphetamine $[(+/-)$ MDMA] on locomotion and serotonin syndrome behavior in the rat. Pharmacol Biochem Behav 32: 835-840.

TFMPP receptor binding database (2004). http://kidb.bioc.cwru. edu/pdsp.php.

Vollenweider FX, Gamma A, Liechti M, Huber T (1998). Psychological and cardiovascular effects and short-term sequela of MDMA ('ecstasy') in MDMA-naïve healthy volunteers. Neuropsychopharmacology 19: 241-251.

Wikstrom M, Holmgren P, Alner J (2004). A2 ( $N$-benzylpiperazine) a new drug of abuse in Sweden. J Anal Toxicol 28: 67-70.

Yamamoto BK, Nash JF, Gudelsky GA (1995). Modulation of methylenedioxymethamphetmine-induced striatal dopamine release by the interaction between serotonin and gammaaminobutyric acid in substantia nigra. J Pharmacol Exp Ther 273: 1063-1070.

Yamamoto BK, Spanos LJ (1988). The acute effects of methylenedioxymethamphetamine on dopamine release in the awakebehaving rat. Eur J Pharmacol 148: 195-203. 